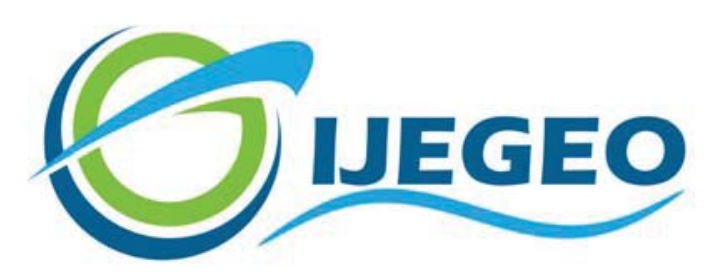

International Journal of Environment and Geoinformatics (IJEGEO) is an international, multidisciplinary, peer reviewed, open access journal.

\title{
Spatial Expansion and Population Growth Analysis of Ogbomoso Metropolis to Forestall Overwhelming Available Infrastructures
}

\author{
S.O. OLAOSEGBA, A. ALAGBE, M.O. OKEGBOLA, B.I. AJISAFE
}

\author{
Chief in Editor \\ Prof. Dr. Cem Gazioğlu \\ Co-Editors Prof. Dr. Dursun Zafer Şeker, Prof. Dr. Şinasi Kaya, \\ Prof. Dr. Ayşegül Tanık and Assist. Prof. Dr. Volkan Demir
}

Editorial Committee (June 2022)

Assoc. Prof. Dr. Abdullah Aksu (TR), Assoc. Prof. Dr. Uğur Algancı (TR), Assoc. Prof. Dr. Aslı Aslan (US), Prof. Dr. Levent Bat (TR), Prof. Dr. Paul Bates (UK), İrşad Bayırhan (TR), Prof. Dr. Bülent

Bayram (TR), Prof. Dr. Luis M. Botana (ES), Prof. Dr. Nuray Çağlar (TR), Prof. Dr. Sukanta Dash (IN), Dr. Soofia T. Elias (UK), Prof. Dr. A. Evren Erginal (TR), Assoc. Prof. Dr. Cüneyt Erenoğlu (TR), Dr. Dieter Fritsch (DE), Prof. Dr. Ç; Prof. Dr. Manik Kalubarme (IN), Dr. Hakan Kaya (TR), Assist. Prof. Dr. Serkan Kükrer (TR), Assoc. Prof. Dr. Maged Marghany (MY); Prof. Dr. Micheal Meadows (ZA), Prof. Dr. Nebiye Musaoğlu (TR), Prof. Dr. Masafumi Nakagawa (JP), Prof. Dr. Hasan Özdemir (TR), Prof. Dr. Chyssy Potsiou (GR), Prof. Dr. Erol Sarı (TR), Prof. Dr. Maria Paradiso (IT), Prof. Dr. Petros Patias (GR), Prof. Dr. Elif Sertel (TR), Prof. Dr. Nüket Sivri (TR), Prof. Dr. Füsun Balık Şanlı (TR), Dr. Duygu Ülker (TR), Prof. Dr. Seyfettin Tsaş (TR), Assoc. Prof. Dr. Ömer Suat Taşkın (TR), Assist. Prof. Dr. Tuba Ünsal (TR), Assist. Prof. Dr. Sibel Zeki (TR) 


\title{
Spatial Expansion and Population Growth Analysis of Ogbomoso Metropolis to Forestall Overwhelming Available Infrastructures
}

\author{
S.O. Olaosegba ${ }^{1 \text { (D) }}$, A. Alagbe ${ }^{\text {(iD) }}$, M.O. Okegbola ${ }^{1 \text { (D) }}$, B.I. Ajisafe ${ }^{1 \text { (i) }}$
}

${ }^{1}$ Department of Surveying and Geoinformatics, Federal School of Surveying, Oyo

${ }^{2}$ Department of GIS, Federal School of Surveying, Oyo

E-mail: olaosegba@fss-oyo.edu.ng

Received 03.10.2020

Accepted 24.09.2021

How to cite Olaosegba (2022). Spatial Expansion and Population Growth Analysis of Ogbomoso Metropolis to Forestall Overwhelming Available Infrastructures, International Journal of Environment and Geoinformatics (IJEGEO), 9(2):009-017 doi. 10.30897/ ijegeo 804755

\begin{abstract}
The requirement of land for an array of uses as population grows and cities open up to further development is at an astronomical rate. This has resulted in effort to convert areas covered by water bodies into dry land. This notwithstanding, land has remain a relatively fixed asset which cannot be massively expanded by any means, but its utilization can be managed to ensure its sustainability. Most human activities are land based hence how land is used have a ripple effect on most aspects of our lives and the environment. The way and manner land is being used relative to population growth of an area must be monitored to avoid environmental degradation. This research attempts an analysis of the Land Use and Land Cover (LULC) changes of Ogbomoso metropolis between the years 1985 and 2015 and makes projections for the next 30years at regular interval of 10years. Secondary data obtained through Remote Sensing were adopted for the research. Landsat imageries TM 1985, 1995 and ETM+ imageries of 2005 and 2015 were downloaded from the Global Land Cover Facility (GLCF) while Remote Sensing techniques was adopted for data processing and analysis. Population data obtained for the study area from the National Population Commission (NPC) were used for the population projection. Land Consumption Rate and Land Absorption Coefficient were introduced to aid in the quantitative assessment of the change. Analysis of the results showed the alarming rate of growth in built-up area between the periods considered and suitable recommendations was made on measures to properly manage such growth.
\end{abstract}

Key words: Spatial Expansion, Population, ISD, Trend Analysis, Future Projection

\section{Introduction}

Land use activities whether converting natural landscapes for human use or changing management practices on human dominated lands have transformed a large proportion of the Earths land surface (Sabzar and Ramachandra, 2016). Land use has been changing ever since human's first began to manage their environment. However, the changes that have taken place over the last 50 years have been especially important and intense as society is becoming increasingly urbanized, while natural ecosystems become deteriorated (Martinez, et al., 2009; Kaya et al., 2014; Islam et al., 2016; Bel Fekih Bousemma et al., 2018; Çelik et al., 2019).

Due to clearing of tropical forests, practicing subsistence agriculture, increasing farmland production and expanding urban centres, the world's landscape is changing in inescapable ways through human actions (Foley, et al., 2005). Due to population growth and expansion in what we use land for (expansion in land use/land cover) as a result of human activities, the study of spatial expansion of our cities have become one of the major areas of research and consequently helped most of the developed country to manage their cities' growth in population and infrastructure. Urbanization therefore, transforms the natural land surfaces to modern land use and land cover such as buildings, roads and other impervious surfaces, making urban landscapes fragmented and complex and affecting the inhabitability of cities (Alberti and Marzluff, 2004).

Urban land use/land cover changes are very dynamic in nature according to Kaya et al., (2015), Mohan (2005) and have to be monitored at regular intervals for sustainable environmental development. Since 1850, while total global population has increased six times, the earth's urban population has increased over 100 times (Hauser, et al., 1982). The world's urban areas, according to United Nation (2012) are gaining an estimated 67 million people per year - about 1.3 million every week and by 2030, approximately 5 billion people are expected to reside in urban areas $-60 \%$ of the projected global population of 8.3 billion. Thus, Clarke et al (1997) concluded that urban growth at the global scale shows no sign of slowing and is occurring even in nations where population growth has stabilized. Anil (2011) therefore posited that it is important to understand the human intervention with the environment which depends upon the natural setting of an area as well as the socioeconomic status of the population. Urban centers with poor planning are diseased by such infections as slum housing conditions, limited coverage of urban services, unreliable service provision, general 
environmental deterioration, confused transport systems, incessant flooding and fire disasters (Egunjobi, 1999; Adetunji and Oyeleye, 2013). It could be deduced from this that poor planning of urban centres always resulted in environmental defect. However, planning which takes place at various spatial levels can help to minimize the impact of urbanization on the environment thus Egunjobi (1999) argues that planning and management are twin requisites for controlling the growth of urbanization and achieving good quality of life for urban dwellers, both permanent and temporary. The study of land use/land cover (LU/LC) changes is very important to have proper planning and utilization of natural resources and their management (Asselman and Middelkoop, 1995).

Land use and Land cover (LULC) data provides useful information regarding developmental, environmental and resource planning applications at regional as well as global scale (Ramachandra et al., 2012). LULC dynamics are analysed through changes in the state of an object or phenomenon by observing it at different times. Accurate and timely detection of change in natural resources provides the basic understanding of the relationships and interactions between human and natural phenomena (Sabzar and Ramachandra, 2016). Ogbomoso is one of the largest cities in Oyo State and has witness a tremendous growth since the period of western rules in Nigeria. The siting of Ladoke Akintola University of technology, a Nursing School and some other commercial centers has recently increase the rate of growth of Ogbomoso. Therefore, an attempt will be made in this study to map out the status of spatial expansion of Ogbomosho between 1985, 1995, 2005 and 2015 with a view to detecting the land consumption rate and the changes that have taken place over the specified time frame, particularly in the built-up area so as to predict possible changes that might take place in the next twenty five years using Geographic Information System tools and remotely sensed data (Incekara et al., 2017).

\section{Statements of the Problem}

Anthropogenic activities have affected the heterogeneous landscape of Ogbomoso metropolis which had made the landscape witnessed remarkable expansion in growth and development within the last few decades. Inflow of humans into the city has increased the infrastructural development which in turn has greatly affected the ecological composition of the ancient city which has witnessed over $400 \%$ population increase. These have resulted to structural challenges such as inadequate facilities, inefficient street layouts and transportation networks, less space for conservation and parks, low agricultural farm lands, high use of carbon energy, land and water.

Hence, there is need to carry out spatial monitoring and detecting the land consumption rate and also make an attempt to predict same and the possible changes that may occur in this study area so that planners can have a basic tool for planning, forecasting and decision making. It is therefore necessary for a study such as this to be carried out for Ogbomosho metropolis to avoid the problems associated with urban growth.

\section{Aim of the Study}

The study attempts to statistically predict the likely changes in landuse/landcover and population of Ogbomoso metropolis and make necessary recommendations towards proper planning for such changes over a given period using geospatial technology. The objectives involved in order to achieve the stated aim were:

i. To design a spatial database respect to the view of reality of the study area such as developed area, green area, water body etc

ii. To acquire spatial data such as Landsat imageries, Google earth imagery and Demographic data

iii. To carry out digital image processing and land cover classification scheme

iv. To determine the trend, nature, rate and magnitude of land use land cover change

v. To estimate the population sizes for different years in the study area.

vi. To Compute land consumption rate and land absorption coefficient

vii. To create a spatial database for spatial and non-spatial data according to processed and estimated parameters in iv - vi above

viii. Predicting the future pattern of land use land cover in the study area from the database

\section{Location of the Study Area}

The study area was Ogbomosho Metropolis in Oyo state, Nigeria. Ogbomosho Geo-political Zone constitutes five local government areas: Ori-ire, Surulere, Ogo-Oluwa, Ogbomosho North and Ogbomosho South Local Governments out of which only Ogbomosho North and Ogbomosho South Local Government Areas form the nucleus of ogbomoso Metropolis. The study area lies between Latitude $07^{\circ} 55^{\prime} \mathrm{N}$ and $08^{\circ} 39^{\prime} \mathrm{N}$ and Longitude $3^{\circ} 05^{\prime} \mathrm{E}$ and $04^{\circ} 27^{\prime} \mathrm{E}$. It is approximately in 347 meters elevation above the mean sea level and area of 263.832sqkm. While Ogbomosho North has it's headquarter at the core Ogbomoso city, Ogbomosho South has it's headquarter at Arowomole Area (towards the outskirt of the city). The climate is equatorial, notable with dry and wet seasons. The average daily temperature ranges between $25^{\circ} \mathrm{C}$ and $35^{\circ} \mathrm{C}$. Agriculture is the main occupation of Ogbomosho people. Ogbomoso is blessed with the following institutions; Ladoke Akintola University of Technology and Bowen University Teaching Hospital, etc. and has such landmarks like Soun Palace, Ajilete FM, Parrot FM etc.

\section{Materials and Methods}

The procedure adopted in this study forms the basis for deriving statistics of land use changes and subsequently in the overall, the findings.

\section{Planning}

The boundary of the study area was determined and source of data was analyzed at this stage of the study. The minimum configuration for the hardware and selection of software to be used were also determined 
and every other aspect of planning towards achieving the afore-stated aim were carried out.

\section{Data Acquisition}

Secondary data source was adopted. The data acquired included satellite imageries, administrative maps, shapefile data and population data of the study area.

\section{Satellite Imageries}

Landsat satellite imageries of the same spatial resolution of 30m of Part of Ogbomosho Geopolitical Zone for four Epochs; that is 1985, 1995, 2005 and 2015 were used as Primary dataset. The imageries were downloaded from Global Land Cover Facilities (GLCF) website using Path and Row of the study area. Both 1985 and 1995 were Landsat Thematic Mapper while that of 2005 and 2015 are Landsat Enhanced Thematic Mapper Plus. The table 1 shows information of the LANDSAT Satellites Imageries used in this study.

\section{Vector Dataset}

Vector data which serve as the secondary dataset for this study was collected and used which included an administrative map and a boundary shapefile of the study area. These were obtained from Geographic Information System department of the Federal School of Surveying, Oyo

The tables show the population of Ogbomoso for 1991 and 20016 population data. The data were obtained from the National Population commission (NPC), Ibadan Office, Oyo State.

Table 1. Information about the Landsat Satellites Imageries Used.

\begin{tabular}{lccl} 
& $\begin{array}{c}\text { ACQUISITION } \\
\text { DATE }\end{array}$ & $\begin{array}{c}\text { PATH } \\
\text { AND } \\
\text { ROW }\end{array}$ & $\begin{array}{c}\text { DATA } \\
\text { SOURCE }\end{array}$ \\
$\begin{array}{l}\text { Landsat } \\
\text { TM }\end{array}$ & $1985 / 12 / 27$ & P191R54 & GLCF \\
$\begin{array}{l}\text { Landsat } \\
\text { TM }\end{array}$ & $1995 / 02 / 06$ & P191R54 & GLCF \\
$\begin{array}{l}\text { Landsat } \\
\text { ETM+ }\end{array}$ & $2005 / 11 / 18$ & P191R54 & GLCF \\
$\begin{array}{l}\text { Landsat } \\
\text { ETM+ }\end{array}$ & $2015 / 11 / 29$ & P191R54 & GLCF \\
\hline
\end{tabular}

Table 2. Years 1991 and 2006 Population Data (Ogbomoso)

\begin{tabular}{llccccc} 
& \multicolumn{3}{c}{ 1991 Population Data } & \multicolumn{3}{c}{ 2006 Population Data } \\
\multicolumn{1}{c}{ L.G.A } & Male & Female & Total & Male & Female & Total \\
Ogbomosho North & 65,657 & 60,625 & 126,282 & 103,319 & 95,401 & 198,720 \\
Ogbomosho South & 32,550 & 31,978 & 64,528 & 51,249 & 49,566 & 100,815 \\
Total & 145,917 & 135,618 & 190,810 & 230,903 & 219,260 & 299,535 \\
\hline
\end{tabular}

\section{Image Enhancement and Processing}

For this study, image preprocessing, Image Enhancement, Image Transformation and Image Classification were carried out by using Arc Map software 10.3 version. The Landsat TM and Landsat ETM+ images downloaded from Global Land Cover Facilities (GLCF) Website had already been accurately rectified and Geo-referenced to a UTM map projection (Zone 31). The nearest neighbour resampling method was adopted to avoid changing the original pixel values of the image data. The images were in bands, and bands 5,4 , and 3 were used to form composite images. The composite imageries were generated and clipped to size of the study area for 1985, 1995, 2005 and 2015 imageries. Supervised image classification method was adopted.

\section{Land Use /Land Cover Classification}

The imageries were categorized using a supervised classification, based on a thorough understanding of image characteristics and landscape complexity. Various clusters (LANDSAT images acquired in 1985, 1995, 2005 and 2015) were defined into five land cover classes, which were built-up area (residential and commercial), vegetation/green area, bare soil, wetland and water bodies. Post classifications were employed through the process classification to vector to determine change in trajectory, land uselland cover.

\section{Ground Truthing}

Pixels were chosen throughout the study area (image) after which ground truthing was done and compared with the classified map, which matched. Enough random pixels were checked and the percentage of accurate pixel gave a fairly good estimate of accuracy of the whole map.

\section{Percentage Rate and Magnitude of Each of Area of Land Use / Land Cover of Each Class Feature}

The total value of the area of Ogbomosho metropolis was obtained in a square kilometre (sq. $\mathrm{km}$ ) as well as the magnitude of the area of each of the classified entities for each year. The percentage rate of the area of land use/land cover for each classified feature was obtained from the ratio of the area of each feature to the total area of the study area.

$$
\mathrm{T}=\mathrm{K} / \mathrm{N} * 100 \quad \text { (Zubair 2006) Eqn } 1
$$

Where $T=$ Percentage growth/change (Trend) in land use/land cover in a particular epoch under consideration, $K=$ Area covered by a land use class in a 
particular epoch and $N=$ Total area covered by all land used/land cover classes at a particular epoch.

\section{Population Size Estimation}

Population trend refers to changes over time and can include changes in ranging behavior (e.g. distance and route) and distribution biogeography (e.g. size of population) and life history (e.g. birth and birth rate). Population dynamic are the major criteria for the environment and development changes in the study area. Population data for year 1991 and 2006 and growth rate (2.6\% according to NPC) were used to obtained 1985 , 1995, 2005, 2015 and forward projection for years 2025 , 2035 and 2045 respectively. A mathematical method of population projection was adopted using the following expressions:

$$
\begin{aligned}
& n=\frac{r}{100} * p v \\
& \text { Eqn } 2 \\
& P R=p v+(n * t) \quad(\text { Forward projection }) \quad \text { Eqn } 3 \\
& P b=p v-(n * t) \quad(\text { Backward projection Eqn } 4
\end{aligned}
$$

Where $\mathrm{n}=$ annual population growth, $\mathrm{r}=$ annual growth rate $(2.6 \%$ for 1991 and 2006$)$

$\mathrm{Pv}=$ Base year population (1991 and 2006 population figures), $\mathrm{t}=$ number of years projected for, $\mathrm{P}_{\mathrm{f}}, \mathrm{P}_{\mathrm{b}}=$ Estimated population $(1985,2005,2015,2025,2035$ and 2045).

\section{Rate of Change of Land Use / Land Cover}

Land use/land cover change rate according to Braniac (2011) is the fraction at which the individual land use type increases/decreases. He went further to give the following expression for determining the rate:

$$
\left.A_{r}=\left(U_{b}-U_{a}\right) * 100\right) /\left(U_{a} * t\right) \quad \text { Eqn } 5
$$

Where $A_{r}=$ annual rate of class, $U_{a}=$ Initial area of class, $\mathrm{U}_{\mathrm{b}}=$ current area of a class and $\mathrm{t}=$ difference in the year (Braniac, 2011).

\section{Land Consumption Rate and Land Absorption} Coefficient

According to Yeates and Garner (1976), Land Consumption Rate (LCR) is the measure of compactness which indicates a progressive of spatial expansion of a city while Land Absorption Coefficient (LAC) is a measure of change in consumption of new urban land by each unit increase in urban population. Using their theory, the Land Consumption Rate (LCR) and Land Absorption Coefficient (LAC) can be computed using the following formula.

$$
\text { L.C.R }=A / P ; \quad \text {. Eqn } 6
$$

Where, $\mathrm{A}=$ area/extent of Built Up in square kilometer and $\mathrm{P}=$ Population at the period

$$
\text { L.A.C. }=\left(\left(A_{2}-A_{1}\right) /\left(P_{2}-P_{1}\right)\right)
$$

Eqn 7

Where, $A_{1}, A_{2}=$ Area / extents (in square $\mathrm{km}$ ) for the early and later years respectively and $\mathrm{P}_{1}, \mathrm{P}_{2}=$ Population figures for the early and later years respectively.

\section{Estimation of Spatial Expansion}

The compound interest formula was also used to project the estimated spatial expansion (Pn) of the town in the year 2025, 2035 and 2045 respectively. The equation is given as follows:

$$
P_{n}=P_{o}(1+r / 100)^{d} \quad \text { Eqn } 8
$$

$$
\text { Therefore, } \mathrm{r}=100\left[\left(P n / P_{0}\right)^{1 / d}-1\right] \quad \text { Eqn } 9
$$

\section{Results \\ Feature Classification Results}

Post classification comparison of the classified images revealed the expansion pattern of the study area as it is

\begin{tabular}{|c|c|c|c|c|}
\hline $\begin{array}{c}\text { Land Use/ Land } \\
\text { Cover }\end{array}$ & $\begin{array}{c}1985 \\
\text { Area }(\mathrm{Sq} . \mathrm{Km})\end{array}$ & $\begin{array}{c}1995 \\
\text { Area (Sq.Km) }\end{array}$ & $\begin{array}{c}2005 \\
\text { Area }(\mathrm{Sq} . \mathrm{Km})\end{array}$ & $\begin{array}{c}2015 \\
\text { Area }(\mathrm{Sq} . \mathrm{Km})\end{array}$ \\
\hline Built-up & 9.518 & 17.684 & 27.872 & 43.587 \\
\hline Vegetation & 132.968 & 126.365 & 115.045 & 99.685 \\
\hline Bare soil & 83.942 & 84.547 & 89.565 & 93.545 \\
\hline Wetland & 36.883 & 34.587 & 30.609 & 26.085 \\
\hline Water body & 0.521 & 0.649 & 0.741 & 0.93 \\
\hline Total & 263.832 & 263.832 & 263.832 & 263.832 \\
\hline
\end{tabular}
concern in different directions, the gradual development of the open spaces between already built up areas in the study area and decreased in the vegetation class shows the dynamics of its expansion. The table 4 shows the sizes of each class feature for the respective years while table 5 shows the percentage changes from one epoch to another.

Table 3. Area of Each Class Feature 
Table 4. Percentage Rate of Increase/Decrease in Area of Each Class Feature

\begin{tabular}{|c|c|c|c|c|c|c|}
\hline \multirow{2}{*}{$\begin{array}{l}\text { Land use/ } \\
\text { Land cover }\end{array}$} & \multicolumn{2}{|c|}{ 1985-1995 } & \multicolumn{2}{|c|}{ 1995-2005 } & \multicolumn{2}{|c|}{$2005-2015$} \\
\hline & $\begin{array}{c}\text { Area } \\
\text { (SQ.KM) }\end{array}$ & $\begin{array}{c}\text { Growth } \\
(\%)\end{array}$ & $\begin{array}{c}\text { Area } \\
\text { (SQ.KM) }\end{array}$ & $\begin{array}{c}\text { Growth } \\
(\%)\end{array}$ & $\begin{array}{l}\text { Area } \\
(\mathbf{K M})\end{array}$ & $\begin{array}{c}\text { Growth } \\
(\%)\end{array}$ \\
\hline Built-up & 8.166 & 3.1 & 10.188 & 3.86 & 15.715 & 5.96 \\
\hline Vegetation & -6.603 & -2.5 & -11.32 & -4.29 & -15.36 & -5.82 \\
\hline Bare soil & 0.605 & 0.23 & 5.018 & 1.9 & 3.98 & 1.51 \\
\hline Wet land & -2.296 & -0.87 & -3.978 & -1.51 & -4.524 & -1.71 \\
\hline Water body & 0.128 & 0.05 & 0.092 & 0.03 & 0.189 & 0.07 \\
\hline
\end{tabular}
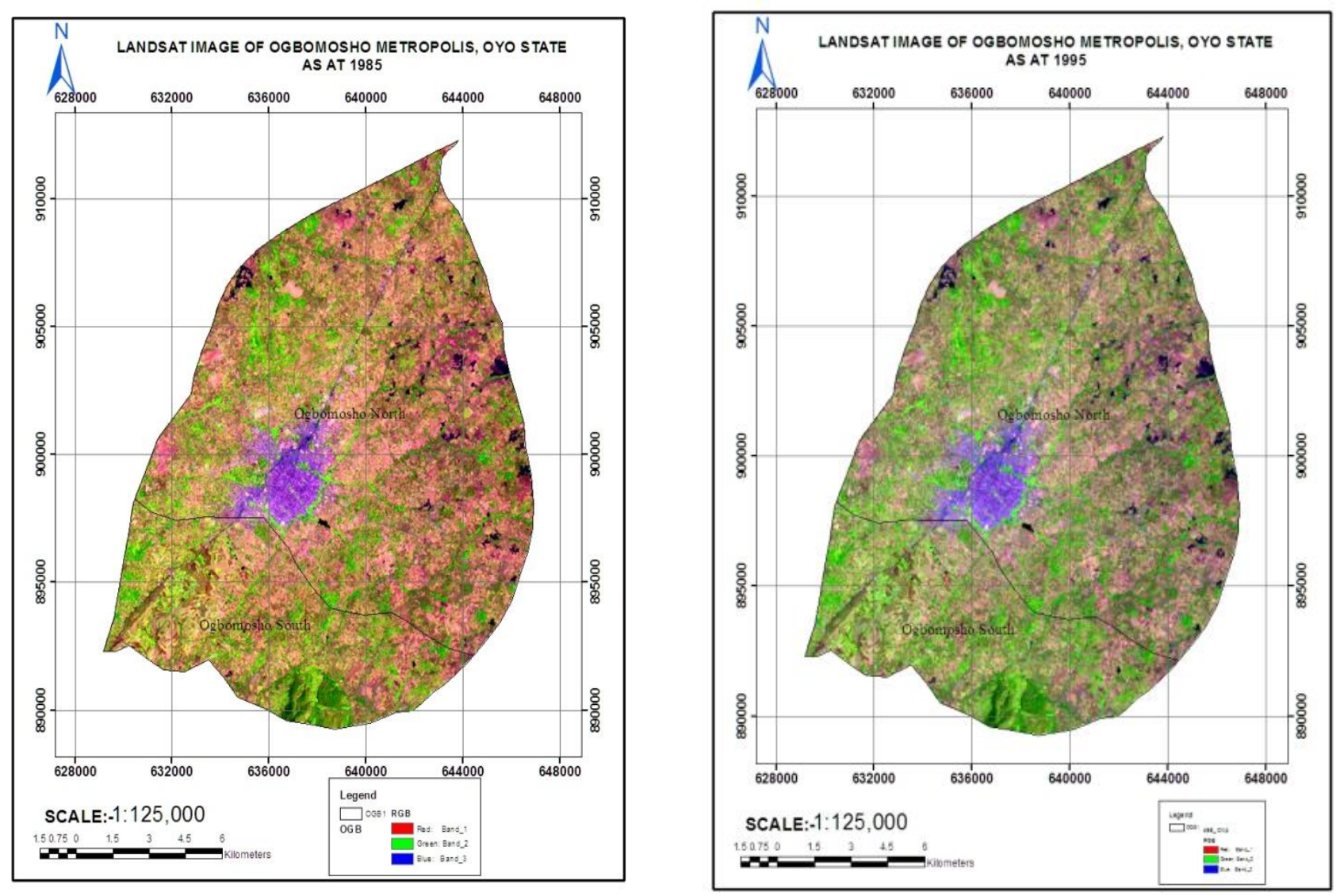


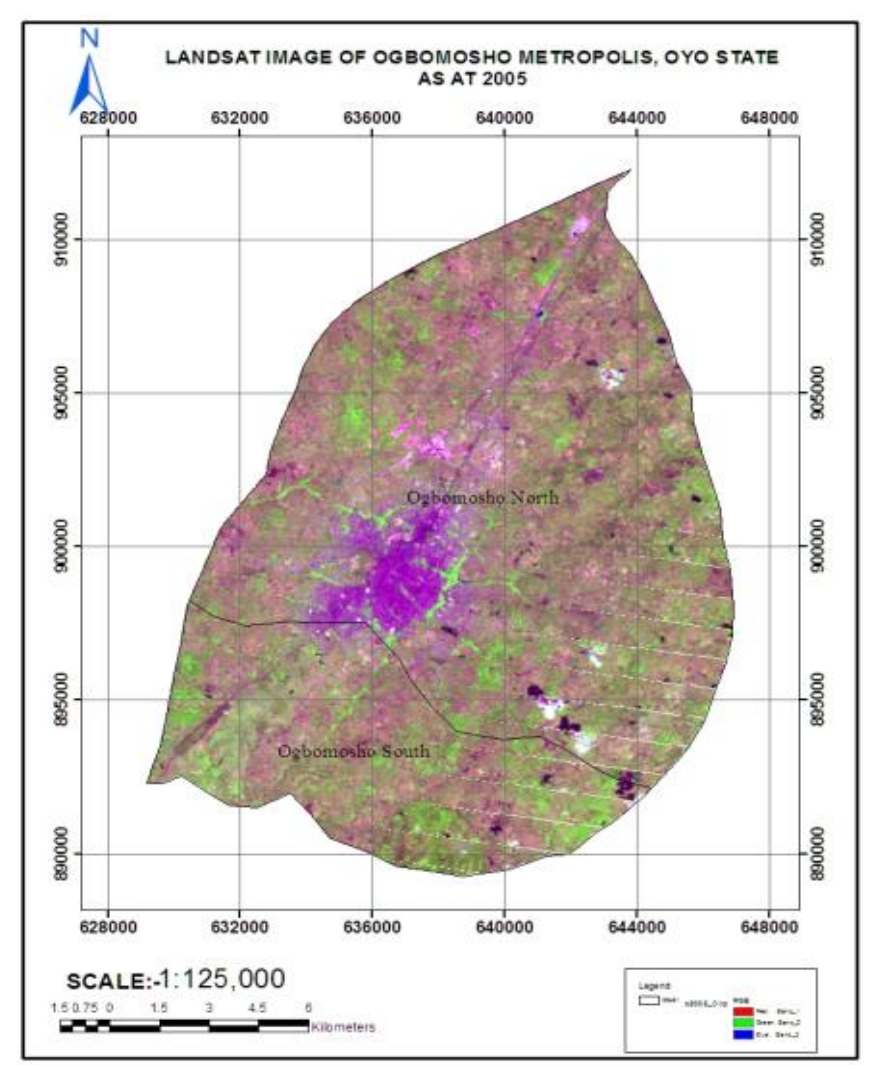

Fig. 2 Years 2005 and 2015 Post Classification Results

Percentage Rate and Magnitude of Each of Area of Land Use / Land Cover of Each Class Feature

The classification of the multi-temporal satellite images into bare soil, built up, vegetation water body and wetland for the four different time periods of 1985 , 1995, 2005 and 2015 has resulted in a highly simplified and abstracted representation of the study area as shown in the table below:

\section{Population Size Estimation}

Table 5. Percentage of Area Covered by each class for each year

\begin{tabular}{|c|c|c|c|c|c|}
\hline \multirow{2}{*}{$\begin{array}{l}\text { Land Use/ Land } \\
\text { Cover }\end{array}$} & & 1985 & 1995 & 2005 & 2015 \\
\hline & & Area (Sq.Km) & Area (Sq.Km) & $\operatorname{Area}(\mathbf{S q} . \mathbf{K m})$ & Area (Sq.Km) \\
\hline \multirow{2}{*}{ Built-up } & AREA(SQ.KM) & 9.518 & 17.684 & 27.872 & 43.587 \\
\hline & $\operatorname{AREA}(\%)$ & 3.61 & 6.7 & 10.56 & 16.52 \\
\hline \multirow{2}{*}{ Vegetation } & AREA(SQ.KM) & 132.968 & 128.365 & 123.045 & 111.685 \\
\hline & $\operatorname{AREA}(\%)$ & 50.4 & 48.65 & 46.64 & 42.33 \\
\hline \multirow{2}{*}{ Bare soil } & AREA(SQ.KM) & 83.942 & 81.547 & 78.565 & 77.545 \\
\hline & $\operatorname{AREA}(\%)$ & 31.82 & 30.91 & 29.78 & 29.39 \\
\hline \multirow{2}{*}{ Wet land } & AREA(SQ.KM) & 36.883 & 35.587 & 33.609 & 30.085 \\
\hline & $\operatorname{AREA}(\%)$ & 13.98 & 13.49 & 12.74 & 11.4 \\
\hline \multirow{2}{*}{ Water body } & AREA(SQ.KM) & 0.521 & 0.649 & 0.741 & 0.93 \\
\hline & $\operatorname{AREA}(\%)$ & 0.2 & 0.25 & 0.28 & 0.35 \\
\hline \multirow{2}{*}{ Total } & AREA(SQ.KM) & 263.832 & 263.832 & 263.832 & 263.832 \\
\hline & $\operatorname{AREA}(\%)$ & 100 & 100 & 100 & 100 \\
\hline
\end{tabular}

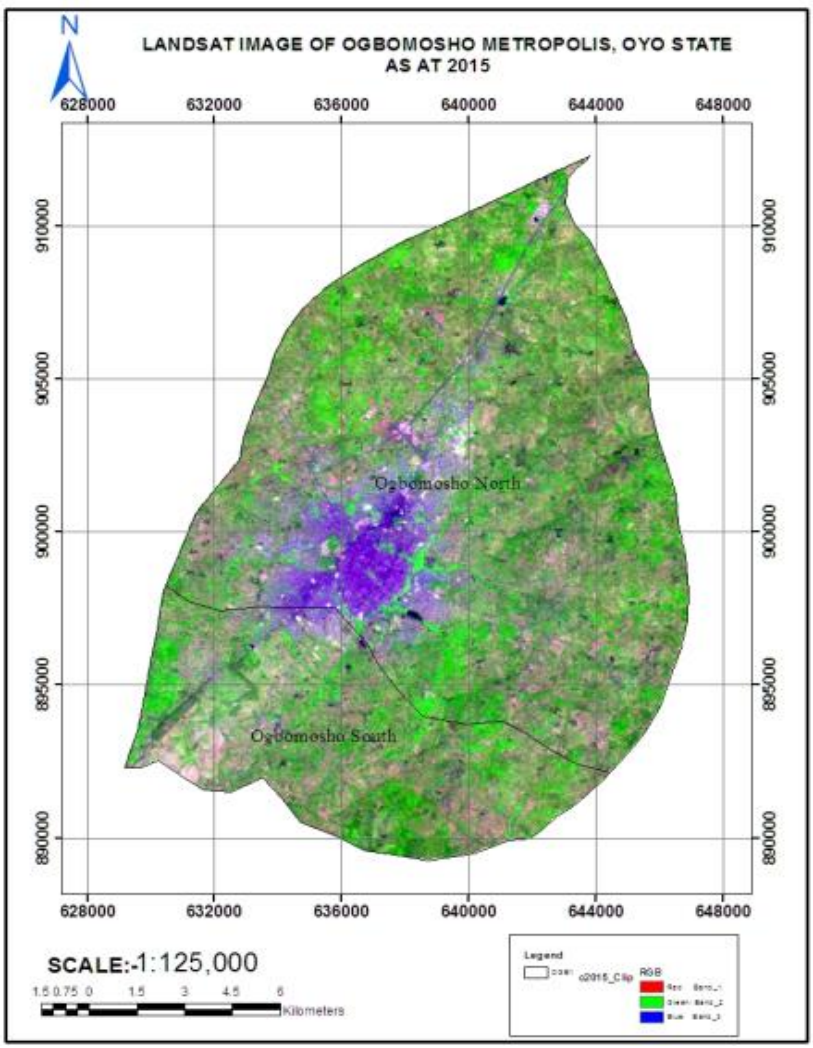

Using the first equation in section 2.7, the annual population growth, n, was computed for the base populations of 1991 and 2006. The annual growth rate of $2.6 \%$ as obtained from the NPC was used in determining the annual population growth for the two base years. The annual population growth of 1991 was used to estimate for the population sizes of 1985 and 1995 while that of 2006 was used to estimate for 2005, 2015, 2025, 2035 and 2045 . The results were shown in the table below: 
Table 6. Population Estimates

\begin{tabular}{cccl} 
YEAR & $\begin{array}{c}\text { POPULATION } \\
\text { FIGURE }\end{array}$ & $\begin{array}{c}\text { GROWTH } \\
\text { PERCENTAGE }\end{array}$ & \multicolumn{1}{c}{ SOURCE } \\
1985 & 262,328 & 2.6 & Researcher's Estimate (using NPC 1991) \\
1991 & 310,815 & 2.6 & National Population Census (NPC) \\
1995 & 343,140 & 2.6 & Researcher's Estimate (using NPC 1991) \\
2005 & 655,058 & 2.6 & Researcher's Estimate (using NPC 2006) \\
2006 & 672,544 & 2.6 & National Population Census (NPC) \\
2015 & $829,919.30$ & 2.6 & Researcher's Estimate (using NPC 2006) \\
\hline 2025 & $1,004,781$ & 2.6 & Researcher's Estimate (using NPC 2006) \\
2035 & $1,179,642$ & 2.6 & Researcher's Estimate (using NPC 2006) \\
\hline 2045 & $1,354,504$ & 2.6 & Researcher's Estimate (using NPC 2006) \\
\hline
\end{tabular}

Table 7. Expansion of Built-Up Area relative to Population Growth Between 1985 and 2015

\begin{tabular}{|c|c|c|c|c|c|c|}
\hline YEAR & $\begin{array}{l}\text { POPULATION } \\
\text { FIGURE }\end{array}$ & $\begin{array}{l}\text { BUILT- } \\
\text { UP }\end{array}$ & L.C.R. & PERIOD & L.A.C. & SOURCE \\
\hline 1985 & 262,328 & 9.518 & 0.000036283 & $1985-1995$ & 0.000101049 & $\begin{array}{l}\text { Researcher's } \\
\text { Estimates }\end{array}$ \\
\hline 1995 & 343,140 & 17.684 & 0.000051536 & $1995-2005$ & 0.000032662 & $\begin{array}{l}\text { Researcher's } \\
\text { Estimates }\end{array}$ \\
\hline 2005 & 655,058 & 27.87 & 0.000042549 & $2005-2015$ & 0.000089871 & $\begin{array}{l}\text { Researcher's } \\
\text { Estimates }\end{array}$ \\
\hline 2015 & 829,919 & 43.59 & 0.000052520 & & & $\begin{array}{l}\text { Researcher's } \\
\text { Estimates }\end{array}$ \\
\hline
\end{tabular}

Table 8. Estimated Spatial Expansion for 2025, 2035 and 2045

\begin{tabular}{cccc} 
YEAR & Estimated Land Area KM $\mathbf{K}^{2}$ & Expansion rate $(\%) *$ & Av. Expansion Rate \\
1985 & 9.518 & \\
1995 & 17.684 & 6.39 \\
2005 & 27.872 & 4.65 \\
2015 & 43.587 & 4.57 \\
2025 & Projected Estimated Land Area & Projected Population \\
2035 & 72.36264 & $1,004,781$ \\
2045 & 120.1356 & $1,179,642$ \\
\hline
\end{tabular}

Land Consumption Rate and Land Absorption Coefficient

The LCR is a measure of compactness of urban sructures and indicates the spatial expansion of a city while LAC is a measure of changes in consumption of new land by unit increase in urban population. Table 4.4 below shows the expansion of Part of Ogbomosho from 1985 to 2015.

\section{Estimation of Spatial Expansion for Built-Up Area}

From the equations 8 and 9, the percentage rates of expansion were compute between 1885 - 1995, 1995 2005 and 2005 - 2015. The average of the three (3) expansion rates was computed to be $5.2 \%$. With the land area of 2015 and the average expansion rate computed, the area of Built-Up environment for the years 2025, 2035 and 2045 were estimated and the results shown in the table below:

\section{Discussion and Conclusion Discussion of Results}

From the result of post-classification process, there seems to be a positive change i.e. increased in three (3) feature classes (Built-Up, Vegetation and Bare Soil) and experienced decreased in only vegetation and wetland between 1985 and 2015. This may be connected to the change in the economic base on the town from farming to other white collar jobs as a result of the creation of 
employment opportunities and increased in social infrastructural amenities affects the land use land cover. It was discovered that with just $3.61 \%$ of built-up area, the population of Ogbomoso was 262,328 in 1985 while the built-up area increased to $6.7 \%$ the population rose to 343,140 . As at 2015, the built-up area has covered $16.52 \%$ of the total land area available and the population has significantly rose to 829,919 . With this trend, it was estimated that by 2025 , the built up area would have covered $27.43 \%$ with population estimate of a little above 1million. It was also estimated that by 2045 , the built up area would have covered $75.60 \%$ with population estimate of over 1.3 million.

The LCR values were categorised into three (3) namely: Low value $(<0.00006)$, moderate Value $(0.00006$ $0.00009)$ and high values $(>0.00009)$. The considerable increase in LCR values in these years are due to rapid development and others socio-economic factors such as shifting of people from congested area towards the outskirts on the open spaces. The LAC result suggests that the rate at which new land are acquired for development is because of non-availability land for further development within Ogbomoso metropolis.

\section{Conclusion}

From all indications, alarming rate of increase in population of Ogbomoso does not have a commensurate rate of infrastructural development. This is very common to most of Nigerian cities and such has resulted in dilapidated conditions of our infrastructure. Most of the sectors have been negatively affected from health facility to educational infrastructures. Majority of our public schools cannot boast of standard class and staff rooms not to mention laboratories and libraries. The existing recreational centers have become graveyards and our roads have nothing to write home about. All these were from the effect of influx of population into the urban centers. This work has also proven that Ogbomoso was no exception to the afore-mentioned problems and if proper control and cautions were not taken within the next twenty years, the situation might be out of control.

Having concluded the work, the following recommendations were made:

i. Government should establish a unit under the office of the Surveyor-General whose responsibility shall be to monitor urban growth at regular interval and advice government accordingly on the measure to take in order to avoid likely disaster associated with over population and congestion of our cities in Nigeria as a whole and Oyo State in particular.

ii. Government should make and implement policies on land use activities of the dwellers such that area meant for agriculture would not be turned into residential as commonly witness across the country.

iii. The city of Ogbomoso is surrounded by other less cities and villages which make up Ogbomoso geo-political zone. Such includes Ajaawa, Iresa-adu, Iresapa, Ikoyi just to mention but a few. It is hereby recommended that government should develop these less cities to make them more attractive and comfortable to live. Such will discourage the rural dwellers and attract others into such towns and villages. The result of that would be that Ogbomoso metropolis become decongested.

iv. In order to fast track the infrastructural development, government should work on internally generated revenue such that whatever is earned from that region can also be used to develop the city - especially education and health care sectors.

v. With the current population and spatial expansion of Ogbomoso, the government should immediately engage in intensive infrastructural development of the city of Ogbomoso before it becomes to record serious disaster and more awareness should be made to inform the dwellers of the town, as population increase, to abide by the rules and regulations that govern land use in the area.

\section{Conflict of interest statement}

We declare that we have no conflict of interest.

\section{References}

Adetunji, M. A., Oyeleye, O. I. (2013). Evaluation of the Causes and Effects of Flood in Apete, Ido Local Government Area, Oyo State, Nigeria, Journal of Civil and Environmental Research, 3(7): 19, New York, USA

Alberti, M., Marzluff, J. (2004). Ecological resilience in urban ecosystems: linking urban patterns to ecological and human function, Urban Ecosyst $2004 ; 7: 241-265$

Anil, P. (2011). A comparison of Landuse and Landcover Change Detection Methods. ASPRSACSM Annual Conference and FIG XXII Congress, 2

Asselman, N. E. M., Middelkoop, H. (1995). Floodplain sedimentation: quantities, patterns and processes, Journal of Earth Surface Processes and Landforms, 20(6): 481-499, 1995

Bel Fekih Bousemma, S., Khebour Allouche, F., Saidane, İ., Mechmech, Y., Bettaieb, T. (2018). State of the art of greenway concept application in Tunisian green policy. A case study of an urban landscape in Sousse city, International Journal of Environment and Geoinformatics, 5(1), 36-50, doi. 10.30897/ijegeo.353818

Celik, B., Kaya, Ş., Alganci, U., Seker, DZ. (2019). Assessment of the relationship between land use/cover changes and land surface temperatures: a case study of thermal remote sensing, FEB Fresenius Environ. Bull., 3, 541

Clarke, K. C., Hoppen, S., Gaydos, L. (1997). A SelfModifying Cellular Automation Model of Historical Urbanization in the San Francisco Bay Area. Environment and Planning B: Planning and Design, 24, 247-261 
Egunjobi (1999). "Our Gasping Cities" An Inaugural Lecture, 1999, University of Ibadan, Ibadan, Oyo State, Nigeria

Foley, J. A., DeFries, R., Asner, G. P., Barford, C., Bonan, G., Carpenter, S. R., Snyder, P. K. (2005). Global Consequences of Land Use, Science, 309(5734), 570-574

Hauser, P. N., Gardner, R. W., Laquian, A. A., ElShakha, S. (1982). Population and the Urban Future. Albany, State University of New York Press, New York

İncekara, A. H., Şeker, D. Z., Tezcan, C. S., Bozkurtoglu, E., Gazioğlu, C. (2017). Interpreting Temperature Based Discontinuity and Roughness of Rock Surfaces by Using Photogrammetric Technique, International Journal of Environment and Geoinformatics, 4(3), 206-213, doi. 10. 30897/ijegeo.348806

Islam, K.., Jasimuddin, M., Nath, B., Nath, T. K. (2016). Quantitative Assessment of Land Cover Change Using Landsat Time Series Data: Case of Chunati Wildlife Sanctuary (CWS), Bangladesh, International Journal of Environment and Geoinformatics, 3(2), 45-55, doi. 10.30897/ ijegeo.306471

Kaya, S., Gazioğlu, C., Sertel, E., Şeker, D.Z., Alganc1, U. (2015). Rapid determination of land use/cover changes using data fusion. The 36th Asian Conference on Remote Sensing "Fostering Resilient Growth in Asia", Metro Manila, Filipinler, 19-23 October 2015.

Kaya, Ş., Pekin, F., Şeker, D. Z., Tanık, A. (2014). An Algorithm Approach for the Analysis of Urban Land-Use/Cover: Logic Filters, International Journal of Environment and Geoinformatics , 1(1), 12-20, doi.10.30897/ijegeo.300722

Martinez, M. L., Pérez-Maqueo, O., Vázquez, G., Castillo-Campos, G., García-Franco, J., Mehltreter, K., Landgrave, R. (2009). Effects of Land Use Change on Biodiversity and Ecosystem Services in Tropical Montane Cloud Forests of Mexico, Journal of Forest Ecology and Management, 258(9), 1856-1863

Mohan, M., (2005). Urban Land Use/Land Cover Change Detection in National Capital Region (NCR) Delhi: A Case Study of Faridabad District. Proceeding of the 8th International Conference on the Global Spatial Data Infrastructure (GSDI-8): From Pharaohs to Geoinformatics

Ramachandra, T. V., Kumar, U., Joshi, N. V. (2012). Landscape Dynamics in Western HimalayaMandhala Watershed, Himachal Pradesh, India, Asian Journal of Geoinformatics, 12(1)

Sabzar, A. K., Ramachandra, T. V. (2016). Land Use Land Cover Change Analysis of Uttara Kannada, Imperial Journal of Interdisciplinary Research (IJIR). 2(4), 2016 ISSN: 2454-1362, 460 - 471

United Nation, UN (2012). World Urbanization Prospects, the 2011 Revision, United Nations Department of Economic and Social Affairs, population Estimate and Projection Section
Yeates, M., Garner, B. (1976). Classification and Change Analysis of the Twin Cities (Minnesota) Metropolitan Area by Multi-Temporal Landsat Remote Sensing, In Remote sensing of Environment, 98(2-3). The North American City, Harper and Row Publication, New York, 317-328

Zubair, A. O. (2006): Change Detection in Land Use and Land Cover Using Remote Sensing Data and GIS (A Case Study of Ilorin and Its Environs in Kwara State), Department of Geography, University of Ibadan, Oyo state, Nigeria. 